\title{
Prinsip Piercing The Corporate Veil Dalam Perseroan Terbatas Dihubungkan Dengan Good Corporate Governance
}

\author{
Sandra Dewi* \\ Fakultas Hukum Universitas Lancang Kuning \\ Jalan Yos Sudarso Km 8, Rumbai, Kota Pekanbaru, Indonesia
}

\begin{abstract}
Abstrak
Tujuan penelitian ini menjelaskan prinsip piercing the corporate veil dapat menunjang terwujudnya GCG dalam rangka mencegah penyalahgunaan kekuasaan pemegang saham. Metode penelitian ini hukum normatif dengan pendekatan perundang-undangan), konsep dan kasus. Hasil penelitian ini dapat dijelaskan bahwa prinsip piercing the corporate veil menunjang terwujudnya GCG dalam rangka mencegah penyalahgunaan kekuasaan pemegang saham. Prinsip piercing the corporate veil tersebut dapat membatasi atau mencegah perbuatan melawan hukum yang dilakukan pemegang saham, komisaris, dan direksi yang memanfaatkan fasilitas perseroan untuk kepentingan pribadi atau penyalahgunaan kekayaan perseroan. Kesimpulan penelitian ini bahwa akibat hukum prinsip piercing the corporate veil terhadap tanggung jawab PT apabila dilanggar menyebabkan tanggung jawab perseroan yang tadinya terbatas menjadi unlimited liability (tanggung jawab tidak terbatas) hingga sampai harta pribadi dari pemegang saham. Dalam perkembangannya, tanggung jawab hukum tidak terbatas ini dapat dibebankan kepada organ perseroan lainnya, seperti komisaris atau direksi apabila terlibat dalam pelanggaran prinsip piercing the corporate veil. Dengan penerapan tanggung jawab pribadi berdasarkan prinsip piercing the corporate veil maka menjadi kewajiban hukum dari organ perseroan meliputi direksi, pemegang saham, dan komisaris yang menyalahgunakan wewenang untuk bertanggung jawab sampai pada harta kekayaan pribadi serta memberikan kepastian dan perlindungan hukum bagi stakeholders (para pemangku kepentingan) yang dirugikan atas kegiatan usaha yang dijalankan para organ.
\end{abstract}

Kata kunci: Perseroan Terbatas, Tanggung Jawab, GCG

\begin{abstract}
The purpose of this study explains the principle of piercing the corporate veil can support the realization of GCG in order to prevent abuse of shareholder power. This research method is normative law with approach of legislation), concept and case. The results of this study can be explained that the principle of piercing the corporate veil support the realization of GCG in order to prevent abuse of shareholder power. The principle of piercing the corporate veil may limit or prevent unlawful acts committed by shareholders, commissioners and directors who utilize the company's facilities for personal gain or misappropriation of company property. The conclusion of this study is that the legal consequences of piercing the corporate veil principle against the responsibility of PT if violated caused the company's previously unlimited liability to unlimited liability to the
\end{abstract}

*Penulis Korespondensi

E-mail: sandradw1998@gmail.com 
private property of shareholders. In its development, this unlimited legal liability may be imposed on other company organs such as commissioners or directors if involved in violation of the piercing the corporate veil principle. By applying personal responsibility based on the principle of piercing the corporate veil, it becomes the legal obligation of the company's organs including directors, shareholders and commissioners who abuse the authority to be responsible to private property and provide legal certainty and protection for stakeholders (stakeholders) who are disadvantaged over the business activities carried out by the organs.

\section{Keywords: Limited Liability Company, Responsibility, GCG}

\section{Pendahuluan}

Tujuan Perseroan Terbatas (PT) akan dapat dicapai apabila organ perusahaan dalam mengelola perusahaannya melaksanakan prinsip-prinsip tata kelola perusahaan yang baik (good corporate governance principle). Sehubungan dengan tujuan PT amanah Pasal 97 Ayat (2) Undang-Undang Nomor 40 Tahun 2007 tentang Perseroan Terbatas maka direksi memiliki posisi dan kekuasaan besar untuk urusan perseroan. Oleh sebab itu, maka salah satu unsur terpenting yang diatur dalam regulasi perusahaan, yaitu mengontrol prilaku dari direksi yang mempunyai posisi dan kekuasaan besar dalam mengelola perusahaan, termasuk menentukan standar perilaku (standart of conduct) untuk melindungi pihak-pihak yang akan dirugikan apabila direksi berprilaku tidak sesuai dengan kewenangannya atau berprilaku tidak jujur dalam menentukan kebijakan-

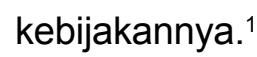

Hubungan antara direksi dengan perseroan merupakan hubungan saling ketergantungan. Satu dengan yang lain saling tergantung, sebagai organ yang dipercayakan untuk melakukan pengurusan perseroan.
Demikian pula hubungan antara direksi dengan dewan komisaris. Status badan hukum PT berpengaruh terhadap tanggung jawab komisaris PT. Secara implisit, tanggung jawab komisaris juga terbatas sebagaimana tercantum dalam Pasal 114 Ayat (6) UndangUndang Nomor 40 Tahun 2007 tentang Perseroan Terbatas bahwa atas nama perseroan, pemegang saham yang mewakili paling sedikit 1/10 (satu per sepuluh) bagian dari seluruh saham dengan hak suara yang sah dapat mengajukan gugatan ke pengadilan negeri terhadap komisaris dan direksi yang karena kesalahan atau kelalaiannya menimbulkan kerugian pada perseroan.

Tanggung jawab pemegang saham secara terbatas merupakan tirai atau benteng yang memisahkan tanggung jawab pemegang saham dengan tanggung jawab pengurus dalam menjalankan kegiatan usaha perseroan. Akan tetapi, tirai tersebut bukan bersifat mutlak dan tidak dapat ditembus sebagaimana diatur pada Pasal 3 Ayat (2) Undang-Undang Nomor 40 Tahun 2007 tentang Perseroan Terbatas. Dengan demikian, maka tirai atau benteng pemisah tanggung jawab terbatas (limited

${ }^{1}$ Bismar Nasution, Tanggung Jawab Direksi dan Komisaris Dalam Pengelolaan Perseroan Terbatas Bank, Makalah yang disampaikan pada Seminar Sehari Tanggung Jawab Pengurus Bank dalam Penegakan dan Penanganan Penyimpanan di Bidang Perbankan Menurut UUPT dan Undang-Undang Perbankan, diselenggarakan oleh Bank Indonesia dan Forum Komunikasi Direktur Kepatuhan Perbankan, Surabaya, tanggal 21 Februari 2008, hlm. 6. 
liability) dari pemegang saham akan tembus dan menjadi hapus (piercing the corporate veil), dan pemegang saham dapat dituntut pertanggungjawaban sepenuhnya tidak terbatas hanya sebesar penyetoran modalnya saja, akan tetapi atas kerugian yang timbul. Pertanggungjawaban pemegang saham perseroan berdasarkan piercing the corporate veil selama ini telah digunakan yurisprudensi. ${ }^{2}$

Prinsip piercing the corporate veil telah diintrodusir dalam Undang-Undang Nomor 1 Tahun 1995 tentang Perseroan Terbatas. Keberlakuan undang-undang ini telah menggantikan beberapa Pasal mengenai PT dalam Kitab Undang-Undang Hukum Dagang/ KUHD (Wetboek van Koophandel voor Indonesien). Undang-Undang Nomor 1 Tahun 1995 kemudian digantikan dengan UndangUndang Nomor 40 Tahun 2007 tentang Perseroan Terbatas yang memperkenalkan beberapa prinsip hukum baru menyangkut organ PT dan mempertahankan prinsip piercing the corporate veil (menembus tirai perseroan) yang memberi pengecualian bagi prinsip tanggung jawab terbatas yang berlaku terhadap pemegang saham PT.

Prinsip piercing the corporate veil dimuat di Undang-Undang Nomor 40 Tahun 2007 tentang Perseroan Terbatas sebagai pengaruh hukum asing umumnya berasal dari hukum Anglo Saxon. ${ }^{3}$ Jika dulu tidak dikenal pertanggungjawaban pribadi pemegang saham, kini ketentuan dalam Pasal 3 Undang-Undang Nomor 40 Tahun 2007 tentang Perseroan Terbatas, diatur pemegang saham perseroan tidak bertanggung jawab secara pribadi atas perikatan yang dibuat atas nama perseroan dan tidak bertanggung jawab atas kerugian perseroan melebihi saham yang dimiliki.

Dalam penerapannya, prinsip piercing the corporate veil tidak dapat diterapkan hanya memperhatikan satu dasar hukum saja, tetapi berbagai peraturan dan ketentuan hukum lain yang berlaku bagi jenis usaha PT. Misalnya, ketentuan perbankan bagi bank yang berbentuk PT atau peraturan-peraturan pasar modal bagi PT yang telah go public. ${ }^{4}$

Pasal 3 Ayat (2) Undang-Undang Nomor 40 Tahun 2007 tentang Perseroan Terbatas telah mengintrodusir tanggung jawab pemegang saham dari suatu perseroan terbatas yang tanggung jawabnya terbatas menjadi tanggung jawabnya tidak terbatas, dalam hal berikut:

1. Persyaratan perseroan sebagai badan hukum belum atau tidak terpenuhi. Dalam hal ini perusahaan belum berbentuk PT, namun telah beroperasi layaknya PT.

2. Dalam hal ini pihak pemegang saham (dalam tampilannya sebagai pendiri/promotor) perusahaan yang bertanggung jawab sampai dengan disahkannya badan hukum perseroan oleh Menteri Kehakiman. Setelah itu, tanggung jawab beralih kepada pihak direksi sampai dengan pendaftaran pengumuman. Setelah pendaftaran dan pengumuman maka yang bertanggung jawab hanyalah perseroan yang bersangkutan, kecuali ada alasan untuk diterapkan prinsip

${ }^{2}$ Chatamarrasjid Ais, Pengaruh Prinsip Piercing the Corporate Veil dalam Hukum Perseroan Indonesia, Jurnal Hukum Bisnis, Volume 22, Nomor 6 Tahun 2003, hlm. 17.

${ }^{3}$ Munir Fuady, Hukum Perusahaan dalam Paradigma Hukum Bisnis, (Bandung: Citra Aditya Bakti, 2002), hlm. 4, 8 dan 61.

${ }^{4}$ Chatamarrasjid Ais, Pengaruh Prinsip...Op.Cit., hlm. 8. 
piercing the corporate veil karena alasan-alasan lain. ${ }^{5}$

3. Pemegang saham yang bersangkutan, baik langsung maupun tidak langsung dengan itikad buruk memanfaatkan perseroan untuk kepentingan pribadi. ${ }^{6}$ Dalam hal ini pemegang saham dikategorikan melakukan perbuatan pribadi, sehingga dapat dimintakan tanggung jawab pribadi.

4. Pemegang saham yang bersangkutan terlibat dalam perbuatan melawan hukum dengan mengatasnamakan perseroan.

5. Pemegang saham yang bersangkutan, baik langsung maupun tidak langsung secara melawan hukum menggunakan kekayaan perseroan, yang mengakibatkan kekayaan perseroan menjadi tidak cukup untuk melunasi utangutang perseroan. Di sini perbuatan pemegang saham termasuk perbuatan pribadi yang bisa dikenakan/dimintakan tanggung jawab pribadi.

Dengan demikian, prinsip tanggung jawab terbatas (limited liability) dalam UndangUndang Nomor 40 Tahun 2007 tentang Perseroan Terbatas tidak bersifat absolut. Dalam pengertian bahwa tanggung jawab terbatas tersebut bersifat relatif. Prinsip ini mengajarkan bahwa sungguhpun suatu PT bertanggung jawab secara hukum hanya terbatas pada harta PT tersebut, tetapi dalam hal-hal tertentu, seperti diatur dalam Pasal 3 Ayat (2) Undang-Undang Nomor 40 Tahun 2007 tentang Perseroan Terbatas tanggung jawab (limited liability) tersebut dapat ditembus (piercing) menjadi unlimited liability. Pertanggungjawaban hukum dapat juga dimintakan terhadap pemegang sahamnya. Bahkan, dalam pengembangannya juga membebankan tanggung jawab hukum kepada organ perusahaan lain, seperti direksi atau komisaris. Namun demikian, ketentuan ini sering dilanggar sebagaimana dijelaskan sebagai berikut.

Meskipun prinsip piercing the corporate veil sudah diatur dalam Pasal 3 Ayat (2) Undang-Undang Nomor 40 Tahun 2007 tentang Perseroan Terbatas, namun pada kenyataannya terdapat kasus-kasus yang seharusnya diputus pengadilan dengan menyatakan pemegang saham dan para organ perusahaan bertanggung jawab sampai harta pribadinya. Namun, dalam putusan pengadilan tersebut tanggung jawab mereka hanya sebatas tanggung jawab pada perseroan yang berarti prinsip piercing the corporate veil tidak diindahkan, seperti pada kasus Bank Century dan PT Lapindo Brantas. Hal ini menimbulkan permasalahan, yaitu tidak menimbulkan efek jera sehingga segala bentuk kecurangan atau perbuatan melawan hukum dengan mengatasnamakan perseroan masih terus terjadi yang pada akhirnya dapat merugikan perekonomian nasional Indonesia.

Pengadilan di Indonesia sudah banyak yang menggunakan prinsip piercing the corporate veil dalam menyelesaikan masalah tanggung jawab PT, sejauh permasalahan itu menyangkut penyalahgunaan kekuasaan atau kewenangan dan menggunakan perseroan untuk kepentingan pribadi ataupun untuk alat

$5 /$ bid. hlm. 30.

${ }^{6}$ Hardijan Rusli, Perseroan Terbatas dan Aspek Hukumnya, (Jakarta: Pustaka Sinar Harapan, 1997), 
untuk melakukan perbuatan melawan hukum dan bahkan untuk melakukan tindak pidana misalnya tindak pidana pencucian uang.

Gios Adhyaksa melakukan penelitian dengan judul "Perlindungan Hukum bagi Nasabah terhadap Kerugian Akibat Pengalihan Asset Berdasarkan Prinsip Penyikapan Tabir Perseroan (Piercing the Corporate Veil) Dalam Kaitannya dengan Pertanggung Jawaban Komisaris", yang dimuat dalam Jurnal Unifikasi Volume 2 Nomor 1 Tahun 2015. Dalam penelitiannya dijelaskan bahwa terhadap sebuah PT di bidang perbankan sesuai dengan bentuk badan usaha dan badan hukum, yaitu UndangUndang Nomor 40 Tahun 2007 tentang Perseroan Terbatas dan Undang-Undang Nomor 10 Tahun 1998 tentang Perbankan dapat dijadikan dasar legalitas untuk mengkaji penerapan prinsip piercing the corporate veil dalam kasus PT Bank Century Tbk dan organorgannya. Piercing the corporate veil bertujuan untuk terciptanya kemakmuran dan kesejahteraan tidak hanya bagi organ (direksi, pemegang saham, dan komisaris) perseroan saja, tetapi juga bagi seluruh stakeholders (nasabah, investor, kreditur, karyawan). Setelah menelaah kasus PT Bank Century Tbk diketahui bahwa terdapat beberapa persoalan hukum yang terjadi serta mengakibatkan perseroan dan stakeholders (para pemangku kepentingan) mengalami kerugian, para organ PT Bank Century Tbk bersama-sama menyalahgunakan wewenang serta memanfaatkan bank untuk kepentingan diri pribadi. ${ }^{7}$

Hasil penelitian Gios Adhyaksa menjelaskan bahwa PT Bank Century Tbk terbukti telah melakukan perbuatan melawan hukum dari awal pendirian PT Bank Century Tbk. Upaya yang dapat dilakukan dalam penerapan tanggung jawab kepada pihak stakeholders (para pemangku kepentingan), yaitu dengan adanya penerapan prinsip piercing the corporate veil. Prinsip piercing the corporate veil merupakan salah satu upaya yang dilakukan Pemerintah untuk memberikan rasa keadilan bagi stakeholders (para pemangku kepentingan), terlihat adanya pemberlakuan tanggung jawab dari organ perseroan secara pribadi sampai kepada harta pribadi dengan menghapuskan tanggung jawab terbatas dari organ (limited liability). ${ }^{8}$

Penelitian Gios Adhyaksa mempunyai persamaan dan perbedaan dengan penelitian ini. Persamaannya, kedua penelitian samasama meneliti mengenai prinsip piercing the corporate veil. Perbedaannya, jika penelitian Gios Adhyaksa meneliti mengenai perlindungan hukum nasabah dikaitkan dengan pertanggungjawaban komisaris, sedangkan penelitian ini meneliti penerapan prinsip piercing the corporate veil dalam tanggung jawab perseroan terbatas dihubungkan dengan Good Corporate Governance (disingkat GCG) dalam rangka mencegah penyalahgunaan kekuasaan pemegang saham. Selain itu perbedaan lainnya, penelitian Gios Adhyaksa menggunakan metode yuridis-empiris, sedangkan pada penelitian yang akan dilakukan menggunakan metode penelitian hukum normatif.

Sulistiowati dan Veri Antoni melakukan penelitian dengan judul "Konsistensi Penerapan Prinsip Piercing the Corporate Veil pada Perseroan Terbatas di Indonesia", yang dimuat dalam Jurnal Yustisia, Edisi 87, Tahun 2013.

${ }^{7}$ Gios Adhyaksa, Perlindungan Hukum bagi Nasabah Terhadap Kerugian Akibat Pengalihan Aset Berdasarkan Prinsip Penyikapan Tabir Perseroan (Piercing the Corporate Veil) Dalam Kaitannya dengan Pertanggung Jawaban Komisaris, Jurnal Unifikasi, Volume 2, Nomor 1, Tahun 2015.

${ }^{8}$ Ibid. 
Penelitiannya bertujuan untuk mengetahui arti penting dan penerapan piercing the corporate veil dalam peraturan perundang-undangan di bidang PT. ${ }^{9}$ Penelitiannya merupakan penelitian yuridis normatif yang mendasarkan pada penelitian kepustakaan guna memperoleh data sekunder. Data yang diperoleh dari asas-asas hukum, peraturan-peraturan, dan buku-buku yang dianalisis dengan menggunakan metode kualitatif. Penelitian kualitatif ini menghasilkan data deskriptif-analitis. Selain itu, dilakukan juga studi untuk membandingkan penggunaan piercing the corporate veil di berbagai negara. Hasil penelitiannya menjelaskan: Pertama, arti penting pengaturan piercing the corporate veil dalam peraturan perundang-undangan di bidang PT karena: (1) untuk memberikan kepastian hukum. (2) keberadaan piercing the corporate veil di undang-undang akan berimplikasi pada sanksi yang tegas sehingga efek jera dapat tercapai. (3) untuk menekan biaya litigasi. (4) untuk memotivasi penerapan piercing the corporate veil. Kedua, prinsip piercing the corporate veil dalam perundangundangan di bidang PT diperluas dari KUHD sampai dengan Undang-Undang Nomor 1 Tahun 1995 dan Undang-Undang Nomor 40 Tahun 2007.

Penelitian Sulistiowati dan Veri Antoni juga mempunyai persamaan dan perbedaan dengan penelitian penulis. Persamaannya, kedua penelitian sama-sama meneliti mengenai prinsip piercing the corporate veil. Selain itu, persamaan lainnya, kedua penelitian menggunakan metode penelitian hukum normatif. Perbedaannya, jika penelitian
Sulistiowati dan Veri Antoni meneliti mengenai konsistensi penerapan prinsip piercing the corporate veil pada PT di Indonesia, sedangkan penelitian yang penulis lakukan meneliti penerapan prinsip piercing the corporate veil dalam tanggung jawab PT dihubungkan dengan GCG dalam rangka mencegah penyalahgunaan kekuasaan pemegang saham.

Try Widiyono melakukan penelitian dengan judul "Perkembangan Teori Hukum dan Prinsip Hukum Piercing The Corporrate Veil dalam UUPT dan Realitasnya serta Prospektif Kedepannya", yang dimuat dalam Jurnal Lex Jurnalica Volume 10 Nomor 1 April 2013. Dalam penelitiannya disebutkan teori badan hukum pertama diciptakan oleh para peletak dasar teori badan hukum hanya untuk menjawab tantangan badan hukum dapat bertindak dalam lalu lintas hukum ekonomi. Teori badan hukum tersebut pada perjalanannya masih perlu untuk disempurnakan, karena ternyata terdapat hubungan hukum dan tindakan hukum para pihak yang terdapat pada pribadi-pribadi yang berada di balik badan hukum yang belum tersentuh oleh hukum. ${ }^{10}$

Tujuan penelitian Try Widiyono untuk menjelaskan perkembangan teori hukum dan prinsip hukum piercing the corporate veil dalam UUPT. Reformasi hukum atas badan hukum dapat dilihat dari dua tonggak sejarah badan hukum, yakni pertama saat lahirnya teori badan hukum yang menitikberatkan pada personifikasi badan hukum seakan-akan sebagai manusia dan kedua pada saat lahirnya prinsip hukum korporasi yang dikenal dengan nama piercing the corporrate veil yang dilatarbelakangi untuk

\footnotetext{
${ }^{9}$ Sulistiowati dan Veri Antoni, Konsistensi Penerapan Prinsip Piercing the Corporate Veil pada Perseroan Terbatas di Indonesia, Jurnal Yustisia, Edisi 87, September-Desember, 2013.

${ }^{10}$ Try Widiyono, Perkembangan Teori Hukum dan Prinsip Hukum Piercing the Corporrate Veil dalam UUPT dan Realitasnya serta Prospektif Kedepannya, Jurnal Lex Jurnalica Volume 10, Nomor 1, April 2013.
} 
mengungkap tabir hukum para pribadi yang berada di balik perseroan, yakni para pemegang saham, dewan komisaris dan direksi. Selain itu, untuk memberikan landasan teoritis dan filsafat agar para pemegang saham, dewan komisaris dan direksi dapat melakukan pengelolaan perseroan secara adil, benar dan profesional serta penuh integritas yang tinggi dan bertanggung jawab kepada stakeholder, yang mana Undang-Undang Nomor 40 Tahun 2007 tentang Perseroan Terbatas secara umum telah meresepsi prinsip hukum tersebut. ${ }^{11}$

Namun demikian, dalam realitanya terdapat pemegang saham yang melanggar prinsip hukum tersebut, antara lain dengan mempengaruhi profesionalisme dan integritas direksi dan dewan komisaris untuk kepentingan share holder tanpa memperhatikan kepentingan stakeholder. Di samping maraknya pemegang saham melakukan perjanjian-perjanjian nomine saham, yang melanggar disclosur principles, baik dari segi informasi maupun tanggung jawab serta bertentangan dengan prinsip GCG sebagai implementasi prinsip hukum tersebut. ${ }^{12}$

Try Widiyono juga melakukan penelitian yang mempunyai persamaan dan perbedaan dengan penelitian ini. Persamaannya, kedua penelitian sama-sama meneliti mengenai prinsip piercing the corporate veil. Perbedaannya, jika penelitian Try Widiyono meneliti mengenai perkembangan teori hukum dan prinsip hukum piercing the corporrate veil dalam UUPT dan realitasnya serta prospek kedepannya, sedangkan pada penelitian ini meneliti penerapan prinsip piercing the corporate veil dalam tanggung jawab PT dihubungkan dengan GCG dalam rangka mencegah penyalahgunaan kekuasaan pemegang saham.

Dari penelitian-penelitian yang telah diuraikan di atas maka dapat dinyatakan bahwa penelitian yang akan dilakukan berbeda, baik substansi maupun metode penelitiannya. Berdasarkan latar belakang yang telah diuraikan di atas maka peneliti tertarik untuk melakukan penelitian ini dengan judul "Prinsip Piercing the Corporate Veil dalam Tanggung Jawab Perseroan Terbatas dihubungkan dengan Good Corporate Governance".

Terkait dengan uraian di atas maka permasalahan dalam penelitian ini, yaitu bagaimana prinsip piercing the corporate veil dapat menunjang terwujudnya GCG dalam rangka mencegah penyalahgunaan kekuasaan pemegang saham? Untuk menjawab pertanyaan tersebut penulis mengunakan pendekatan yuridis normatif. Tujuan yang diharapkan dari penelitian ini untuk menjelaskan prinsip piercing the corporate veil dapat menunjang terwujudnya GCG dalam rangka mencegah penyalahgunaan kekuasaan pemegang saham.

\section{Metode Penelitian}

\section{Pendekatan penelitian}

Pendekatan yang digunakan dalam penelitian ini statute approach (pendekatan perundang-undangan), conceptual approach (pendekatan konsep) dan case approach (pendekatan kasus). Pendekatan perundangundangan dilakukan dengan menelaah semua undang-undang dan regulasi yang bersangkut paut dengan isu hukum yang sedang ditangani. Pendekatan Perundang-undangan digunakan

${ }^{11} / \mathrm{bid}$.

${ }^{12}$ Ibid. 
dalam penelitian ini untuk mencari dan membahas konsistensi dan kesesuaian antara suatu undang-undang dengan undang-undang lainnya atau antara undang-undang dengan Undang-Undang Dasar Negara Kesatuan Republik Indonesia Tahun 1945. Hasil dari telaah tersebut merupakan suatu argumen untuk memecahkan isu yang dihadapi, yaitu mengenai penerapan prinsip piercing the corporate veil dalam tanggung jawab PT dihubungkan dengan GCG dalam rangka mencegah penyalahgunaan kekuasaan pemegang saham.

Pendekatan konseptual beranjak dari pandangan-pandangan dan prinsip-prinsip yang berkembang di dalam ilmu hukum. ${ }^{13}$ Dengan menggunakan pendekatan konseptual dalam penelitian ini, dipelajari pandang-pandangan dan prinsip-prinsip di dalam ilmu hukum, peneliti akan menemukan ide-ide yang melahirkan pengertian-pengertian hukum, konsep-konsep hukum, dan asas-asas hukum relevan dengan isu yang dihadapi. Pemahaman akan pandangan-pandangan dan prinsip-prinsip tersebut merupakan sandaran bagi peneliti dalam membangun suatu argumentasi hukum dalam memecahkan isu yang dihadapi yang dalam hal ini mengenai penerapan prinsip piercing the corporate veil dalam tanggung jawab PT dihubungkan dengan GCG dalam rangka mencegah penyalahgunaan kekuasaan pemegang saham.

Pendekatan kasus yang digunakan dalam penelitian ini dilakukan dengan cara menelaah kasus terkait dengan isu tentang prinsip piercing the corporate veil dan prinsip GCG. Kasus yang dibahas pada penelitian ini adalah kasus pada
PT Lapindo Brantas dan kasus pada Bank Century.

\section{Sifat penelitian}

Sejalan dengan permasalahan dalam penelitian ini maka metode penelitian hukum yang digunakan bersifat hukum doktrinal. Penelitian hukum doktrinal disebut juga sebagai penelitian hukum normatif yang merupakan penelitian kepustakaan, yaitu penelitian data sekunder. ${ }^{14}$

Metode yuridis normatif yang digunakan dalam penelitian ini dengan alasan untuk menganalisis data yang mengacu kepada norma-norma yang terdapat dalam peraturan perundang-undang. Metode yuridis normatif ini mengacu pula kepada penelitian yang mengarah kepada dasar filosofis, khususnya yang berkaitan dengan landasan filosofis penerapan prinsip piercing the corporate veil dalam tanggung jawab PT dihubungkan dengan GCG.

\section{Jenis data}

Jenis data yang digunakan berupa data kualitatif, yaitu peneliti menyajikan data yang berupa kata atau kalimat, yang selanjutnya disusun secara utuh dalam bentuk penulisan hukum. ${ }^{15}$ Bahan-bahan hukum bersifat normatif-prespektif, digunakan terutama untuk mengkaji permasalahan hukum yang terkait dengan substansi peraturan hukum positifnya (ius constitutum) yang sifatnya mengatur penerapan prinsip piercing the corporate veil dalam tanggung jawab PT dihubungkan dengan GCG, berdasarkan kekuatan mengikatnya diklasifikasikan sebagai bahan hukum primer,

${ }^{13}$ Peter Mahmud Marzuki, Penelitian Hukum, (Jakarta: Kencana Prenada, 2011), hlm. 93. hlm. 11-12.

${ }^{14}$ Roni Hanitijo Soemitro, Metodologi Penelitian Hukum dan Jurimetil, (Jakarta: Ghalia Indonesia, 2000),

${ }^{15}$ Lexy J. Moleong, Metodologi Penelitian Kualitatif, (Bandung: Remaja Rosdakarya, 2001), hlm. 34. 
bahan hukum sekunder dan bahan hukum tersier. $^{16}$

\section{Metode pengambilan data}

Pengambilan data penelitian dilakukan dengan teknik studi dokumen. Teknik studi dokumen ini salah satu cara dalam melakukan library research (studi kepustakaan). Teknik studi dokumen, yaitu mengumpulkan bahanbahan hukum bersifat normatif-perspektif, dilakukan dengan cara penelusuran, pengumpulan data sekunder mengenai objek penelitian, baik secara konvensional maupun dengan menggunakan teknologi informasi, seperti internet dan lain-lain.

\section{Metode analisis data}

Data yang diperoleh dikelompokkan dan disusun secara sistematis dan selanjutnya dianalisis secara analisis kualitatif, yaitu analisis berupa kalimat dan uraian. ${ }^{17}$ Metode yang digunakan analisis yuridis, yaitu analisis mendasarkan pada teori-teori, konsep dan peraturan perundang-undangan. Setelah itu, data yang diperoleh disusun secara sistematis dan untuk selanjutnya analisis kualitatif dipakai untuk mencapai penjelasan yang dibahas.

Dalam penelitian hukum normatif, alat analisis hukumnya berupa teori-teori, asas, prinsip dan konsep-konsep hukum. Alat analisis ini digunakan untuk menafsirkan hasil penelitian yang berupa bahan-bahan hukum bersifat normatif-prespektif yang diinteraksikan dengan hasil analisis fakta kemasyarakatan bersifat empiris-deskriptif. Analisis ini bertujuan menghasilkan, menstrukturkan dan mensiste- matisasi temuan-temuan hukum baru yang menjadi dasar untuk pengambilan kesimpulan dan pengembangan teori dan konsep baru, ${ }^{18}$ sehingga tujuan akhir penelitian hukum ini dapat tercapai, yaitu menemukan penerapan prinsip piercing the corporate veil dalam tanggung jawab PT dihubungkan dengan GCG.

\section{Pembahasan}

\section{Prinsip Piercing The Corporate Veil Dapat Menunjang Terwujudnya GCG}

Prinsip-prinsip Organic for Economic Corporation and Development (OECD) berkenaan dengan GCG mencakup lima bidang utama, yaitu (1) hak para pemegang saham (shareholders) dan perlindungannya. (2) peran karyawan dan pihak-pihak yang berkepentingan (stakeholders) lainnya. (3) pengungkapan (disclosure) yang akurat dan tepat waktu. (4) transparansi sehubungan dengan struktur dan operasi perseroan. (5) tanggung jawab dewan (maksudnya dewan komisaris maupun direksi) terhadap perusahaan, pemegang saham, dan pihak-pihak yang berkepentingan lainnya. Secara ringkas prinsip-prinsip tersebut dapat dirangkum sebagai: perlakuan yang setara (equitable treatment atau fairness), transparansi (transparency), akuntabilitas (accountability), dan responsibilitas (responsibility). Prinsip-prinsip dasar tersebut sifatnya tidak mengikat dan memberikan pedoman kepada negara-negara untuk memperbaiki pengelolaan perusahaan di negara mereka.

Undang-Undang Nomor 40 Tahun tentang Perseroan Terbatas sejauh ini telah mengakui keberadaan dan mengakomodasi berbagai

${ }^{16}$ Soerjono Soekanto, Pengantar Penelitian Hukum, (Jakarta: UI Press, 1986), hlm. 52.

${ }^{17}$ Achmad Ali, Menjelajahi Kajian Empiris Terhadap Hukum, (Jakarta: Yasrif Watampone, 2008), hlm. 188.

${ }^{18} \mathrm{M}$. van Hoecke dalam Bernard Arief Sidharta, Refleksi tentang Struktur Ilmu Hukum, (Bandung: CV Mandar Maju, 2000), hlm. 154-155. 
prinsip maupun doktrin-doktrin modern yang berlaku saat ini. Tetapi, kesulitan yang terjadi seberapa konkrit penerapan dan pemenuhan prinsip dan doktrin dimaksud dalam UndangUndang Nomor 40 Tahun tentang Perseroan Terbatas, terutama terhadap upaya penegakan hukumnya. Meskipun undang-undang memberikan peluang dan kesempatan untuk mengajukan gugatan perkara kehadapan persidangan, tetapi kebanyakan kasus pelanggaran terhadap prinsip dan doktrin tersebut tidak transparan diungkap pada publik atau diselesaikan di luar pengadilan. Pada praktiknya, banyak dijumpai berbagai macam bentuk pelanggaran pada setiap sektor usaha termasuk pada institusi perbankan dan perusahaan-perusahaan pembiayaan. ${ }^{19}$

Tanggung jawab dalam PT pada prinsipnya sebatas atas harta yang ada dalam PT tersebut. Itu pula sebabnya disebut "terbatas" (limited), yakni terbatas dari segi tanggung jawabnya. Dengan demikian, para pemegang saham, anggota direksi atau dewan komisaris tidak pernah bertanggung jawab secara pribadi. Artinya, jika ada gugatan dari pihak manapun, harta pribadi dari pemegang saham, anggota direksi atau dewan komisaris pada prinsipnya tidak boleh ikut disita. Namun, pertanggungjawaban terbatas tersebut tidaklah mutlak karena adanya prinsip piercing the corporate veil.

Penerapan piercing the corporate veil ke dalam tindakan PT menyebabkan tanggung jawab hukum tidak hanya dimintakan dari PT tersebut, tapi pertanggungjawaban hukum dapat juga dimintakan kepada pemegang sahamnya, bahkan dalam pengembangannya penerapan prinsip piercing the corporate veil juga membebankan tanggung jawab hukum kepada anggota direksi atau dewan komisaris. Keadaan ini memberikan suatu pemahaman bahwa tidak selamanya transaksi sebagaimana dimaksud dalam Pasal 36 Undang-Undang Nomor 40 Tahun tentang Perseroan Terbatas merupakan prakarsa dari pemegang saham, melainkan dapat mengemuka dikarenakan adanya inisiatif yang timbul, baik dari kalangan pengurus maupun pengawas PT. Sehingga segala sesuatu terjadi tidak secara serta merta, melainkan diperlukan adanya suatu proses pembuktian terlebih dahulu. Kendala yang mungkin dihadapi bilamana PT dimaksud dimiliki oleh keluarga, baik pengurus maupun pengawasnya berasal dari kalangan keluarga yang bersangkutan. Dapat dikatakan bahwa tidak terdapat pengaturan yang spesifik terhadap eksistensi pendirian PT oleh merekamereka yang berstatus sebagai keluarga.

Selain dari pembebanan permasalahan piercing the corporate veil pada direksi dan dewan komisaris sehubungan dengan eksistensi Pasal 36 Undang-Undang Nomor 40 Tahun tentang Perseroan Terbatas maka GCG memiliki pendekatan lain, yakni seputar permasalahan kepemilikan dan pengendalian (ownership dan control). Pemegang saham yang memiliki kontrol sebenarnya memiliki insentif secara lebih dekat untuk memonitor perusahaan serta manajemen yang memberikan pengaruh positif bagi corporate governance. Sebaliknya, pemegang saham pengendali juga berpotensi untuk berkonflik dengan pemegang saham lain, khususnya pemegang saham minoritas. Konflik ini akan

\footnotetext{
${ }^{19}$ Syarif Bastaman, Junaidi, dan Ari Wahyudi Hertanto of Bastaman \& Partners, Indonesia: How to Implement Good Corporate Governance, International Financial Law Review, (London: PW Reproprint Ltd, 2003), hlm. 116.
} 
memberikan akibat buruk ketika pengendali perusahaan melakukan eksploitasi perusahaan yang dikontrolnya, dengan cost yang juga ditanggung para pemegang saham lain, khususnya para pemegang saham minoritas.

Pemegang saham minoritas bukan satusatunya korban, pengendali perusahaan sendiri akan menanggung cost dari buruknya corporate governance dalam bentuk rendahnya valuasi atas nilai saham yang dimiliki pada perusahaan bersangkutan, terbatasnya akses ke pasar saham, dan kesulitan dalam mewujudkan rencana-rencana bisnis serta mengakses potensi pasar yang ada di luar.

Agar memiliki kemampuan dalam melakukan kontrol, pengendali perusahaan tidak harus memiliki lebih dari $50 \%$ hak suara. Kombinasi para pemegang saham antara pengendali perusahaan dengan pemegang saham yang pasif (yang tidak menggunakan hak suaranya), dapat mengendalikan perusahaan dengan hak suara $30 \%$ atau bahkan kurang. Cara lain menggunakan saham dengan hak suara khusus, misalnya pengendali hanya punya $10 \%$ saham, tetapi tiap saham memiliki 10 hak suara, sedangkan $90 \%$ saham yang dipegang para pemegang saham lainnya, hanya memiliki satu suara per lembar saham. Dari contoh ini, pengendali yang cuma memiliki $10 \%$ dapat memiliki hak suara di atas $50 \%$, tetapi hanya memperoleh $10 \%$ dari keseluruhan dividen perusahaan. ${ }^{20}$

Misalnya Mr. Z sebagai pengendali menggunakan transaksi antara perusahaan $A$ dan perusahaan $C$ untuk kepentingan ekonomis pribadinya. Para pihak yang melakukan transaksi, dibuat seolah-olah terlihat tidak memiliki hubungan afiliasi. Perusahaanperusahaan yang didirikan di luar negeri, yang struktur kepemilikannya tidak diketahui secara jelas, sering digunakan dalam banyak transaksi, seperti tunneling. ${ }^{21}$ Transaksi, seperti ini secara teknis legal, tetapi bagaimanapun juga hadirnya tunneling terjadi karena lemahnya hak-hak pemegang saham. Tunneling saat ini merupakan tantangan bagi regulator dan pengadilan. Regulator dan pengadilan membutuhkan sumber daya dan keahlian yang cukup dalam memeriksa transaksi yang seolaholah wajar, tetapi sebenarnya merugikan pemegang saham minoritas. ${ }^{22}$

Penerapan prinsip piercing the corporate veil sebenarnya bukanlah sederhana karena memerlukan pembuktian yang dalam. Terhadap kasus-kasus tertentu tidaklah mudah, sebagaimana tergambarkan dari kutipan ini: "It is very difficult to give a satisfactory analysis or classification of types of case in which the court will lift the veil of corporate. Someone cannot predict with certainly whether or not the court will do so in a particular case". ${ }^{23}$

Selain seputar pembebanan prinsip piercing the corporate veil, secara umum transaksi perusahaan yang bertentangan dengan peraturan perundang-undangan atau anggaran dasar pada umumnya dideskripsikan sebagai tindakan ultra vires. Dalam bahasa umumnya dikenal sebagai suatu pelampauan kewenangan dari suatu PT. Terminologi ultra vires dipakai khususnya pada tindakan

\footnotetext{
${ }^{20}$ Indra Surya dan Ivan Yustiavandana, Penerapan Good Corporate Governance: Mengesampingkan Hak-hak Istimewa demi Kelangsungan Usaha, (Jakarta: Kencana Prenanda Media Group, 2006), hlm. 31-34.

${ }^{21}$ Ibid, hlm. 35.

${ }^{22}$ Ibid, hlm. 110-112.

${ }^{23}$ Arsul Sani, Litigasi dalam UUPT, makalah yang disampaikan pada Konferensi Perkembangan Akhir Undang-Undang Perseroan Terbatas, Jakarta, 27-28 September 1995, hlm. 12-13.
} 
perseroan yang melebihi kekuasaan yang diberikan oleh anggaran dasar atau oleh peraturan yang melandasi pembentukan perseroan tersebut.

Dalam pasal-pasal Undang-Undang Nomor 40 Tahun tentang Perseroan Terbatas tidak ada dinyatakan tegas atau secara eksplisit bahwa tanggung jawab direksi terbatas. Namun demikian, sebagaimana halnya tanggung jawab terbatas pemegang saham, juga berlaku terhadap anggota direksi. Hal tersebut dapat dilihat dari Undang-Undang Nomor 40 Tahun tentang Perseroan Terbatas Pasal 97 Ayat (5) secara acontrario dapat diartikan bahwa apabila anggota direksi tidak bersalah dan tidak lalai menjalankan tugasnya maka ia tidak bertanggung jawab penuh secara pribadi. Jadi, anggota direksi tidak secara tanggung renteng bertanggung jawab atas kerugian itu. Direksi memiliki tanggung jawab yang terbatas sama seperti tanggung jawab pemegang saham perseroan.

Untuk memberikan ilustrasi korelasi antara Pasal 36 Undang-Undang Nomor 40 Tahun tentang Perseroan Terbatas dengan teori piercing the corporate veil maka terlihat faktorfaktor yang dapat menciptakan adanya hubungan-hubungan dimaksud. Salah satu sinyal yang ditanggapi oleh penyusun UndangUndang Nomor 40 Tahun tentang Perseroan Terbatas tersirat dalam ketentuan Pasal 36.

Terdapat beberapa contoh yang mengindikasikan bahwa pemegang saham yang memiliki kontrol sebenarnya mempunyai insentif secara lebih dekat untuk memonitor perusahaan serta manajemen yang memberikan pengaruh positif bagi corporate governance. Kendali semacam ini lebih dikenal sebagai suatu bentuk control of ownership. Sebaliknya, pemegang saham pengendali juga berpotensi untuk berkonflik dengan pemegang saham lain, khususnya pemegang saham minoritas.

Pengendali perusahaan dapat melakukan kontrol, tanpa harus memiliki lebih dari 50\% hak suara. Kombinasi para pemegang saham antara pengendali perusahaan dengan pemegang saham yang pasif (yang tidak menggunakan hak suaranya), dapat mengendalikan perusahaan dengan hak suara $30 \%$ atau bahkan kurang atau dengan cara menggunakan saham dengan hak suara khusus. Misalnya, setiap satu saham memiliki 10 hak suara, sedangkan saham-saham lain yang dipegang para pemegang saham lainnya, hanya memiliki satu suara per lembar saham. Dari contoh ini, pengendali yang hanya memiliki saham $10 \%$ dapat memiliki hak suara di atas $50 \%$.

Regulator dalam Undang-Undang Nomor 40 Tahun tentang Perseroan Terbatas menunjukkan kinerjanya dengan memberlakukan ketentuan Pasal 36. Tentu pasal ini bukan merupakan pasal yang bersifat mandiri, melainkan pasal dalam Undang-Undang Nomor 40 Tahun tentang Perseroan Terbatas yang terintegrasi dengan ketentuan pasal-pasal lainnya. Permasalahan lain yang timbul terhadap peristiwa terjadinya kepemilikan silang (cross holding) dapat langsung menunjuk pemegang saham sebagai pelaku ataukah sebaliknya.

Sesuai dengan segala sesuatu yang telah dipaparkan di atas maka dapat disampaikan bahwa pemegang saham tidak serta merta secara langsung dapat dipersalahkan. Titik tolaknya beranjak dari teori piercing the corporate veil. Pemegang saham berdasarkan teori ini pada prinsipnya dapat langsung dimintakan pertanggungjawaban atas kemungkinan pelanggaran yang dilakukannya sehubungan dengan adanya peluang control of ownership. Namun demikian, direksi pun selaku 
organ terdepan dari perusahaan dapat dipertanyakan seputar kinerjanya sebagai pihak yang diberikan wewenang untuk melakukan pengurusan sebuah PT.

Keadaan ini memicu biasnya pemikiran, di satu sisi pemegang saham lebih memiliki kepentingan akan perusahaan yang dimilikinya, sedangkan di lain pihak direksi atas kewenangan pengurusan perseroan yang diberikan kepadanya justru terbuka peluang untuk melakukan berbagai bentuk penyimpangan yang mengatasnamakan kepentingan bisnis, sehingga perangkat perundang-undangan menjadi terabaikan. Memang prinsip piercing the corporate veil beranjak dari perbedaan substansial antara kepentingan pemegang saham dengan kepentingan PT. Oleh karenanya, ada suatu kondisi bahwa kehendak pemegang saham melampaui kehendak dari sebuah PT, yaitu dengan mempergunakan PT hanya sebagai alat/kendaraan untuk menjalankan kepentingan pemegang saham semata dan mengabaikan berbagai kepentingan perundang-undangan yang berlaku. Salah satu prilaku penyimpangan tersebut terkait kepemilikan silang (cross holding) dimaksud.

Sementara itu, direksi dalam menjalankan kinerjanya pun memiliki otoritas sedemikian rupa dapat menjalankan transaksi-transaksi yang dilakukan oleh sebuah PT. Atas alasan pembenar untuk mengamankan bisnis perusahaan maka salah satu upaya yang dilakukan dengan menerapkan struktur transaksi cross holding. Apabila terbukti demikian maka direksi dapat dimintakan pertanggungjawabannya, bahkan sampai kepada tanggung jawab pribadi karena telah melakukan perbuatan yang melanggar ketentuan Pasal 36 Undang-Undang Nomor 40 Tahun tentang Perseroan Terbatas dan ketentuan perundang-undangan terkait lainnya. Apalagi terhadap transaksi tersebut ternyata berakibat pada kerugian yang bermuara pada meruginya PT, bahkan terhadap para pemangku kepentingan. Pengecualian diberikan sepanjang direksi telah menjalankan fungsi fiduciary-nya secara konsisten, sehingga terhadapnya dapat dikecualikan sebagai pihak yang dibebani tanggung jawab atas peristiwa transaksi cross holding jika memenuhi ketentuan Pasal 97 Ayat (5) Undang-Undang Nomor 40 Tahun tentang Perseroan Terbatas.

Meskipun demikian, terhadap praktek cross holding kecil kemungkinan direksi tidak terlibat di dalam transaksinya, baik secara langsung maupun tidak langsung. Berdasarkan Undang-Undang Nomor 40 Tahun tentang Perseroan Terbatas komisaris pun dapat dijadikan sebagai objek berlakunya teori piercing the corporate veil. Bila ditinjau Pasal 114 Undang-Undang Nomor 40 Tahun tentang Perseroan Terbatas, komisaris sebagai pengawas perseroan terbatas juga memiliki kewajiban fidusia (fiduciary duty).

Kendala yang paling mungkin terjadi bagi pihak ketiga yang berada di luar lingkup PT, yaitu bagaimana seseorang dapat mengetahui bahwa sebuah PT telah melakukan pelanggaran Pasal 36 Undang-Undang Nomor 40 Tahun tentang Perseroan Terbatas. Khususnya mengingat bahwa peluang pihak ketiga untuk menembus suatu transaksi yang dibuat oleh sebuah PT teramat sulit. Alasannya tidak lain terhadap transaksi-transaksi ini akan berstatus teramat rahasia bagi pihak yang terlibat didalamnya yang lazim terikat dengan perjanjian kerahasiaan.

Selanjutnya, dikatakan bahwa notaris merupakan salah satu pilar dalam transaksitransaksi yang dilakukan oleh suatu PT, dari sejak mendirikan sampai tahap likuidasi. 
Jabatan notaris dikehendaki hukum untuk membantu dan melayani masyarakat yang membutuhkan alat bukti tertulis autentik mengenai keadaan, peristiwa atau perbuatan hukum, termasuk PT. Dengan demikian, notaris memiliki peran tersendiri dalam transaksi yang dilakukan oleh PT. Apakah satu dari sekian banyak transaksi termasuk dalam kategori transaksi cross holding sudah barang tentu notaris yang bersangkutan lebih mengetahui. Kendala yang mungkin timbul apakah notaris memiliki otoritas yang begitu kuat untuk melarang perseroan melakukan transaksi dimaksud.

Selanjutnya, apakah undang-undang secara tegas memberlakukan larangan untuk berbuat sesuatu yang ditujukan kepada notaris dengan memberikan sanksi hukum yang signifikan. Pada bagian ini lebih merupakan proposisi yang mengarah terhadap bagaimana sinergi konstruktif yang dapat dibangun dalam rangka menegakkan ketentuan UndangUndang Nomor 40 Tahun tentang Perseroan Terbatas khususnya Pasal 36. Dalam melaksanakan transaksi ini setidaknya akan melibatkan beberapa profesi, antara lain notaris, advokat, akuntan publik, appraisal, dan bankir.

Pemerintah telah berupaya untuk melakukan langkah-langkah konkritnya, tetapi sepertinya langkah konkrit ini tidak cukup apabila tidak mengikutsertakan partisipasi dari kalangan profesi yang diantaranya telah disebutkan di atas, untuk bersama-sama menegakkan ketentuan Pasal 36 Undang-Undang Nomor 40 Tahun tentang Perseroan Terbatas dimaksud.

Pertanyaannya bagaimana hal tersebut dapat direalisasikan? Perlu untuk dilakukan telaah mendalam tentang kemungkinan untuk disusunnya peraturan pemerintah yang eksistensinya sebagai pelaksana dari upaya implementasi Pasal 36 Undang-Undang Nomor
40 Tahun tentang Perseroan Terbatas. Rumusan terhadap pembatasan dalam melaksanakan profesinya setidaknya dapat diatur dalam kode etik masing-masing profesi. Namun demikian, pengaturan dalam kode etik belum tentu dapat memberikan suatu komitmen pelaksanaan yang fundamental tanpa adanya sanksi yang diintegrasikan terhadap pihak-pihak yang melanggar ketentuan perundangundangan dimaksud.

Permasalahannya tidak jelas sanksi yang dapat dijatuhkan berdasarkan Undang-Undang Nomor 40 Tahun tentang Perseroan Terbatas kepada PT yang melanggar ketentuan Pasal 36 dimaksud. Oleh karenanya, sebelum ada ketentuan yang mengatur tentang peran profesi dalam transaksi kepemilikan silang (cross holding) ini maka masing-masing kelompok profesi harus senantiasa berpegang teguh pada etika dan tanggung jawab profesinya. Hal ini terkait dengan tingkat kesadaran hukum dari masing-masing profesi dalam menjalankan aktivitasnya dengan berlandaskan pada tatanan moralitas masing-masing individu yang harus dijunjung tinggi.

\section{Kesimpulan}

Akibat hukum prinsip piercing the corporate veil terhadap tanggung jawab PT apabila dilanggar menyebabkan tanggung jawab perseroan yang tadinya terbatas pada modal disetor/harta perseroan saja menjadi unlimited liability (tanggung jawab tidak terbatas) hingga sampai harta pribadi dari pemegang saham. Dalam perkembangannya tanggung jawab hukum tidak terbatas ini dapat dibebankan kepada organ perusahaan, seperti komisaris atau direksi apabila komisaris atau direksi tersebut juga terlibat dalam pelanggaran prinsip piercing the corporate veil. Dengan penerapan tanggung jawab pribadi berdasarkan 
prinsip piercing the corporate veil maka akan terlihat adanya suatu kewajiban hukum dari pihak organ perseroan yang menyalahgunakan wewenang untuk bertanggung jawab secara pribadi sampai pada harta kekayaan pribadi serta memberikan kepastian dan perlindungan hukum bagi stakeholders yang dirugikan atas kegiatan usaha yang dijalankan para organ.

\section{Saran}

Kepada pembuat undang-undang dalam hal ini legislatif dan eksekutif disarankan membuat pengaturan mengenai penerapan prinsip piercing the corporate veil yang tegas khususnya mengenai pelaksanaan penjatuhan sanksi terhadap organ perseroan, sehingga tidak perlu menunggu putusan pengadilan terhadap perseroan itu sendiri yang akan dilakukan "piercing" terhadapnya.

\section{Referensi}

Achmad Ali. 2008. Menjelajahi Kajian Empiris terhadap Hukum. Jakarta: Yasrif Watampone.

Bernard Arief Sidharta. 2000. Refleksi tentang Struktur IImu Hukum. Bandung: CV Mandar Maju.

Chatamarrasjid Ais. Pengaruh Prinsip Piercing the Corporate Veil dalam Hukum Perseroan Indonesia. Jurnal Hukum Bisnis. Volume 22. Nomor 6. Tahun 2003.

Gios Adhyaksa. Perlindungan Hukum bagi Nasabah terhadap Kerugian Akibat Pengalihan Aset Berdasarkan Prinsip Penyikapan Tabir Perseroan (Piercing the Corporate Veil) Dalam Kaitannya dengan Pertanggung Jawaban Komisaris. Jurnal Unifikasi. Volume 2. Nomor 1. Tahun 2015.

Hardijan Rusli. 1997. Perseroan Terbatas dan Aspek Hukumnya. Jakarta: Pustaka Sinar Harapan.

Indra Surya dan Ivan Yustiavandana. 2006. Penerapan Good Corporate Governance: Mengesampingkan Hak-hak Istimewa Demi Kelangsungan Usaha. Jakarta: Kencana Prenanda Media Group.

Lexy J. Moleong. 2001. Metodologi Penelitian Kualitatif. Bandung: Remaja Rosdakarya.

Munir Fuady. 2002. Hukum Perusahaan dalam Paradigma Hukum Bisnis. Bandung: Citra Aditya Bakti.

Peter Mahmud Marzuki. 2011. Penelitian Hukum. Jakarta: Kencana Prenada.

Roni Hanitijo Soemitro. 2000. Metodologi Penelitian Hukum dan Jurimetil. Jakarta: Ghalia Indonesia.

Soerjono Soekanto. 1986. Pengantar Penelitian Hukum. Jakarta: UI Press.

Sulistiowati dan Veri Antoni. Konsistensi Penerapan Prinsip Piercing the Corporate Veil pada Perseroan Terbatas di Indonesia. Jurnal Yustisia. Edisi 87. September-Desember 2013.

Try Widiyono. Perkembangan Teori Hukum dan Prinsip Hukum Piercing the Corporrate Veil dalam UUPT dan Realitasnya serta Prospektif Kedepannya. Jurnal Lex Jurnalica. Volume 10. Nomor 1. April 2013. 